Summer 2014

\title{
The Politics of Law and the Laws of Politics: The Political Paradoxes of Transnational Constitutionalism
}

\author{
Pablo Holmes \\ University of Brasilia, pabloholmes@unb.br
}

Follow this and additional works at: https://www.repository.law.indiana.edu/ijgls

Part of the International Law Commons, Law and Politics Commons, and the Transnational Law

\section{Commons}

\section{Recommended Citation}

Holmes, Pablo (2014) "The Politics of Law and the Laws of Politics: The Political Paradoxes of Transnational Constitutionalism," Indiana Journal of Global Legal Studies: Vol. 21 : Iss. 2 , Article 6. Available at: https://www.repository.law.indiana.edu/ijgls/vol21/iss2/6

This Article is brought to you for free and open access by the Law School Journals at Digital Repository @ Maurer Law. It has been accepted for inclusion in Indiana Journal of Global Legal Studies by an authorized editor of Digital Repository @ Maurer Law. For more information, please contact rvaughan@indiana.edu.

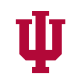

JEROME HALL LAW LIBRARY

INDIANA UNIVERSITY

Maurer School of Law
Blooming ton 


\title{
The Politics of Law and the Laws of Politics: The Political Paradoxes of Transnational Constitutionalism
}

\author{
PABLO HOLMES ${ }^{*}$
}

\begin{abstract}
This essay addresses the ongoing debate on transnational constitutionalism and the theoretical assumptions related to the possibilities of internal politicization of transnational governance. After reconstructing the debate on the transnationalization of law and the emergence of fragmented forms of transnational governance, I engage with the description of emerging forms of constitutional law within the fragmented legal regimes of global governance. After doing that, I explore the assumption exposed by some legal scholars, which insists on the possibility of an internal politicization of legal discourse as a way to challenge the so-called "rule of experts" in transnational law. Drawing on the social-theoretical and political-philosophical formulations of Claude Lefort, I will then address what I call the social conditions of the politicization of law. My claim is that the very possibility of carrying out a certain politics of law depends on features, typical of the political constitutionalization of law, which do not seem to be present in transnational governance.
\end{abstract}

\section{INTRODUCTION}

Ubi societas, ibi jus: where there is society, there must also be law. This meaning of Ulpiano's famous quote, which students are used to hearing during their first months of law school, refers to the fact that any form of society needs some kind of social norms to hold it together.

* Pablo Holmes is an assistant professor at the Institute of Political Science of the University of Brasilia, Brazil. He has a law degree and a master of law from the Federal University of Pernambuco and a $\mathrm{PhD}$ in sociology from the University of Flensburg, Germany. He published "Verfassungsevolution in der Weltgesellschaft," at Nomos Publishing, from Baden-Baden, among other articles in scientific journals in Latin America and Europe.

Indiana Journal of Global Legal Studies Vol. 21 \#2 (Summer 2014)

(C) Indiana University Maurer School of Law 
Hence, if we live today in an increasingly transnational world society in which social forms of interaction and communication in different social sectors such as the economy, science, sports, and mass communication no longer seem to operate exclusively limited by the political boundaries conformed by the territorial jurisdiction of national legal orders, ${ }^{1}$ that famous dictum should hold true on this level. ${ }^{2}$ Transnational law seems to be in an evolutionary demand for a transnational world society.

Moreover, from a sociological perspective, one can say that the complexity of a given society is decisive in determining the complexity of its legal system. ${ }^{3}$ It does not mean that society evolves in a steady course of improvements toward development or "civilization." Rather, it means that social complexity on the basal level must correspond to some social structures that deal with similar complexity on the normative level, such as a system of rules. In the case of a transnationalizing world society, it is not difficult to identify the emergence of broad processes of juridification in the last two or three decades. These processes are not only extremely complex, but also correspond to the growing atopical character of social communication on a global level. Meanwhile, these mechanisms have become one of the most important objects of studies in different fields of scholarly investigation.

Considering the observation that emerging forms of law operate beyond the borders of nation-states, we must also have in mind another implication of this fact. The implication is grounded in common knowledge that every lawyer bears in mind when dealing with practical legal matters, even if not consciously. It can be formulated as a complementary dictum to the former: Where there is law, there must also be some kind of legal framework of second order in which legal decisionmaking takes place.

The practical knowledge implied in this assumption states that a social norm can only have legal value if it is possible to assert whether or not it might be considered valid within a particular legal order. ${ }^{4}$ In

1. See ludger Pries, Die Transnationalisierung Der sozialen Welt [The TRANSNATIONALIZATION OF THE SOCLAL WORLD] 9-47 (2008) (Ger.) (providing a discussion of the transnationalization of society). See also John W. Meyer, Globalization: Sources and Effects on National States and Societies, 15 INT'L SoC. 233 (2000); Saskia Sassen, Territory and Territoriality in the Global Economy, 15 INT'L SoC. 372 (2000).

2. AndREAs Fischer-Lescano, Globalverfassung: Die Geltungsbegründung DER MENSChENREChTE [Global Constitution: THE JUSTIFICATION OF HuMAN RightS] 67-98 (2005) (Ger.).

3. See NikLas Luhmann, Law as a Social System 147-155 (Fatima Kastner et al. eds., Klaus A. Ziegert trans., 2004) (1993).

4. See id. at 98-108. See also Ralf Christensen \& Andreas Fischer-Lescano, Die Einheit der Rechtsordnung: Zur Funktionsweise der holistischen Semantik [THE UNITY OF 
the legal theoretical tradition some have called attention to the existence of rules of recognition, ${ }^{5}$ which indicate the last grounds of validity of norms in a given system. Others have pointed out the logical necessity of supposing the existence of a grounding rule (Grundnorm), which would furnish other legal norms with derivate validity. ${ }^{6}$ Within contemporary legal theory, this sort of explanation for legal validity, which resorts to logical, factual, or moral forms of legitimacy, does not appear to be useful or necessary anymore. Instead of trying to suppose theoretical foundations, legal theory looks for the positive legal foundations of validity in the legal system itself, namely in the internal conditions set by a pool of constitutional rules that regulate legal competencies and the material limits of normative power.

Accordingly, a theoretical discourse has gradually emerged about the existence of transnational legal orders functioning within their own internal constitutional frameworks. By constitutional framework, here, I mean of course not the political arrangement of democratic constitutionalism, but the existence of some kind of second-order law or legal rules, which register within the transnational legal order the problem of legal reflexivity. By conceiving the existence of some constitutional legal framework beyond the existence of political constitutions, I follow to a great extent the thread left by Günther Teubner and David Sciulli. ${ }^{7}$ The controversial claims around this point will be addressed later on in this essay. With regard to global and transnational law, this claim would imply the following: If global lawwhich transcends the boundaries of the territorially-segmented political system of a world society-exists, then a constitutional framework from which it is possible to derive a set of criteria for determining whether a legal norm is valid must also exist. At least we should speak about constitutional problems emerging where the existence of political constitutions of nation-states can no longer bind legal communication to

THE LEGAL ORDER: The FUnCTIONALITY OF THE HOLISTIC SEMANTICS], 4 ZEITSCHRIFT FÜR RECHTSPHILOSOPHIE 8, 8-14 (2006) (Ger.).

5. See H.L.A. HART, THE CONCEPT OF THE LAW 92 (4th prtg. 1967).

6. HANS KELSEN, PURE THEORY OF LAW 193-95 (Max Knight trans., 1967) (1934).

7. See generally DAVID SCIULLI, THEORY OF SOCIETAL CONSTITUTIONALISM: FOUNDATIONS OF A NON-MARXIST CRITICAL THEORY (1992) (explaining the rationale, reasoning, and background underlying societal constitutionalism); GUNTHER TEUBNER, CONSTITUTIONAL FRAGMENTS: SOCIETAL CONSTITUTIONALISM AND GLOBALIZATION (Gareth Norbury trans., 2012) (exploring the function of constitutionalism-both within nationstates and societally in general - in a transnational society); Gunther Teubner, Societal Constitutionalism: Alternatives to State-Centred Constitutional Theory?, in Transnational GovernanCE and Constitutionalism 3 (Christian Joerges et al. eds., 2004) [Hereinafter TRANSNATIONAL GOVERNANCE] (presenting trends of development and the features that must be present in societal constitutionalism). 
political democratic processes. ${ }^{8}$ As we are going to see, the emerging debate on transnational constitutionalism that now has been prevalent for more than a decade points to nondemocratic forms of legal reflexivity that seem to create legal orders beyond the state..$^{9}$

In what follows, I will attempt to deal with the problem of legal transnationalization as an emerging social phenomenon that 'puts different forms of constitutional discourses at stake. For many scholars, constitutional discourse is crucial for politically framing legal decision making on a transnational level. Accordingly, the political outcomes of legal decisions on this level are partially determined by the: set of constitutional principles or by the "constitutional mindset" 10 operating in a given legal system. ${ }^{11}$ Hence, the possibilities of politicization of global governance are limited to the question of which constitutional discourse would be hegemonic in each regime at a given time. New constitutional methodologies or discourses could then be useful for

8. Marcelo Neves, Transconstitutionalism 2 (Kevin Mundy trans., 2013) (2009).

9. For more than ten years, there has been an ongoing theoretical discussion about constitutional pluralism. This debate certainly began in Europe, following the process of "legal Europeanization," which was politically decided by the nation states. After the drafting of the first seminal papers on constitutional pluralism, which focused mainly on the multiplicity of legal orders with different levels of jurisdiction, this debate became more and more related to the parallel discussion on the fragmentation of international law. Further, the increasing attention given to the growing tendency of legalization of transnational social processes in the field of international relations enriched this debate. In recent years, transnational and global constitutionalism became more than wishful thinking-constituting a field of study, which is not necessarily guided by normative assumptions of political democracy. After many symposia, books, theses, and even autonomous journals (like Global Constitutionalism published by Cambridge University Press) the discussion about transnational forms of constitutionalization has clearly become a debate focused on the problems of global governance, beyond the institutional framework of the nation state. See generally TRANSNATIONAL GOVERNANCE, supra note 7 (collecting and discussing the "normative and theoretical foundations of the law governing relations between citizens"). See also id. at 3; Eric Stein, Lawyers, Judges, and the Making of a Transnational Constitution, 75 AM. J. INT'L L. 1 (1981) (presenting an early NorthAmerican account of the issue); Neil Walker, The Idea of Constitutional Pluralism, 65 MOD. L. REV. 317 (2002) (proposing a "rehabilitated" language of constitutionalism); Christian Walter, Constitutionalizing (Inter)national Governance: Possibilities for and Limits to the Development of an International Constitutional Law, 44 GER. Y.B. INT'L L. $170(2001)$

10. See Martti Koskenniemi, Constitutionalism as Mindset: Reflections on Kantian Themes About International Law and Globalization, 8 THEORETICAL INQUIRIES L. 9 (2006) (describing a view of constitutionalism as a mindset rather than the traditional use of constitutional vocabulary).

11. See, e.g., Sonja Buckel \& Andreas Fischer-Lescano, Gramsci Reconsidered: Hegemony in Global Law, 22 LEIDEN J. INT'L L. 437, 448 (2009) (describing a "hegemonic law" wherein the constitutional mindset is formed under particular social conditions of the "historical bloc" and other social praxes). 
courts in their task of coping with social problems on a transnational level.

These assumptions have many legal and political theoretical implications. They seem to assume that, given that national politics can no longer deal with a great part of the regulatory problems arising from the new waves of transnationalization, internal politicization of global legal regimes could replace national, state-centered political struggles and the functions they have performed for national societies. Law could then be the last terrain of social process politicization either in the form of struggles for hegemony or a "quasi-scientific" legal reasoning over social demands on the social adequacy of law.

This essay challenges the assumption that the politics of law is a social achievement that can be taken for granted as a consequence of the mere existence of a legal system. To do that, I address the following questions: Is it possible to politicize transnational and international law from within, relying exclusively on different legal or constitutional mind-sets? Can the "political dimension" of transnational constitutionalism replace political constitutionalism as it was known in the nation-state? After reconstructing the general lines of what can be called a new transnational constitutionalism, I will draw on a socialtheoretical reflection on the work of Claude Lefort. I will thus argue that any internal politicization of transnational law must be grounded in institutional structures that must be functionally equivalent to what is commonly known as the political arrangement of democratic constitutionalism. This is necessary if transnational law is to provide social and political inclusion, as intended by the political constitutional order of the so-called Keynesian-Westphalian State.

\section{LEgal TRANSNATIONALizATION AND GLOBAL GoveRnANCE: NEW FORMS OF REGULATION}

Anyone who attempts to understand how emerging transnational forms of regulation operate must look beyond the highly simplified vocabulary of state-centered realism-common in the in fields of international relations and political science-and pay attention to the interlocking relationship between law and different sectors of world society. Global regimes of governance resemble a "disparate disorder" of organizations, institutions, and jurisdictions that are in more disagreement than the structured outcomes of rational decisionmaking led by nation-states. ${ }^{12}$ Descriptions that depict global governance as the

12. ANDREAS FISCHER-LEsCANo \& GUNTHER TEUBNER, REgIME-KOLLISIONEN: ZUR FRAGMENTIERUNG DES GLOBALEN RECHTS 19 (2006) (Ger.). 
result of hegemonic or homogeneous blocks of political power represented by states are barely able to describe the complexity of a post-national constellation and the pluralism of the transnational regulatory dynamic. ${ }^{13}$

To this extent, the scholarly debate on the legalization of global policy regimes ${ }^{14}$ points to important developments in the evolution of global law and its relations with the emerging forms of governance, even if it also remains partially attached to certain theoretical prejudices of neoclassical economics. ${ }^{15}$ Yet, the most prolific reflections on the emergence of global legal regimes are still produced by those following the theoretical legal thread left by Philip Jessup in 1956. In Jessup's striking definition, legal theory should use "instead of international law,' the term 'transnational law' to include all law which regulates actions or events that transcend national frontiers," whether involving state or nonstate actors. ${ }^{16}$ Transnational law should include "both public and private international law," as well as "other rules which do not wholly fit into such standard categories." 17 In contrast to "international," which refers to phenomena taking place "between" states, the use of the word "transnational" for designating these emerging legal regimes refers to phenomena taking place "beyond," "across," or "through" states. ${ }^{18}$

Indeed, as the regulatory power of the state becomes more and more relativized, more room is left to social organizations such as corporations, universities, sports federations, and information networks for producing their own forms of social regulation. ${ }^{19}$ From the standpoint of legal realism and legal pluralism, the intuition that society produces legal mechanisms and social forms of regulation that

13. See Robert O. KeOHANe, AFTER Hegemony: CoOperation and Discord IN the WORLD POLITICAL ECONOMY 56-58 (1984).

14. See Kenneth W. Abbott et al., The Concept of Legalization, 54 INT'L ORG. 401 (2000).

15. Pablo Holmes, Verfassungsevolution iN DER WeltgesellschafT: DifferenZierungsPRobleme DES RECHTS UND DER POLITIK IM ZEITALTER DER GLOBAL GOVERnANCE [CONSTITUTIONAL EVOLUTION IN THE WORLD SOCIETY: PROBLEMS OF Differentiation of LaW and Politics in the ERA of Global Governance] 182-83 (2013) (Ger.).

16. Philip C. Jessup, TRANSNATIONAL LAW 2 (1956).

17. See id. at 2.

18. See Craig Scott, "Transnational Law" as Proto-Concept: Three Conceptions, 10 GER. L.J. 859, 866 (2009).

19. See Rodney Bruce Hall \& Thomas J. Biersteker, The Emergence of Private Authority in the International System, in The EMERGENCE OF PRIVATE AUTHORITY IN Global Governance 3, 3-10 (Rodney Bruce Hall \& Thomas J. Biersteker eds., 2002). 
go wide beyond "state law" is not new. ${ }^{20}$ Yet, the "living law" (lebendes $R e c h t)^{21}$ of society seems to gain new autonomy thanks to the radical process of transnationalization. A careful observation of the regulatory dynamics in today's world society should demonstrate that transnational governance is in many ways influenced by societal processes of regulation, which are explicitly in concurrence with national and international political processes of state lawmaking.

Through informal, and sometimes not clearly legal-even though also not clearly illegal-mechanisms, big business is able to translate its interests into the language of public regulation in numerous ways. ${ }^{22}$ Although this phenomenon is arguably not new, the amplitude of its influence has never been as considerable as in the last decades. ${ }^{23}$ Moreover, assigning the cause of this shift solely to "neoliberal hegemony in economic thought" would be nothing but a hasty politicization of theoretical analysis. ${ }^{24}$ Rather, one should look at the roots of these processes, which clearly rely on the economic and institutional transformations brought with the intensification of economic transnationalization. Consequently, firms, as well as other transnational and supranational organizations, can pressure state agents and political bodies by means of blackmailing and forum (and regime) shopping. ${ }^{25}$ Even more interestingly, the cases of informal networks of governance, such as those gravitating around the Basel

20. See, e.g., Stewart Macaulay, The New Versus the Old Legal Realism: "Things Ain't What They Used to Be", 2005 WIS. L. REV. 365; Boaventura de Sousa Santos, The Law of the Oppressed: The Construction and Reproduction of Legality in Pasargada, 12 LAW \& SOC'Y REv. 5 (1977).

21. See Eugen Ehrlich, Fundamental Principles of the Sociology of Law 81 (1936).

22. See Sol Picciotto, Regulating Global Corporate Capitalism, 165-71 (2012); Colin Crouch, The Global Firm: The Problem of the Giant Firm in Democratic Capitalism, in THE OXFORD HANDBOOK OF Business AND GOVERNMENT 148, 161-68 (David Coen et al. eds., 2010).

23. See Deniz Igan et al., A Fistful of Dollars: Lobbying and the Financial Crisis 6 (Int'1 Monetary Fund, Working Paper No. 287, 2009), available at http://www.imf.org/external/ pubs/ft/wp/2009/wp09287.pdf (pointing out political lobbying as one of the major causes of the market instability that led to financial crisis of 2008 , and providing "suggestive evidence that the political influence of the financial industry might have the potential to have an impact on financial stability"). See also Joseph Schumpeter, Cronies and Capitols: Businesspeople Have Become Too Influential in Government, ECONOMIST, Aug. 10, 2013.

24. See Colin Crouch, The Strange Non-Death of NeOliberalism 1-23 (2011).

25. See Colin Crouch, Modelling the Firm in its Market and Organizational Environment: Methodologies for Studying Corporate Social Responsibility, 27 ORG. STUD. 1533,1545 (2006). 
Committee, are in a position to deeply affect state policy on a national level. 26

Besides that, one can hardly deny that, in the last decades, supranational organizations such as the United Nations Conference on Trade and Development (UNCTAD), the World Bank, the World Trade Organization (WTO), and the International Monetary Fund (IMF), as well as regional organizations such as the European Union (EU) and the North American Free Trade Agreement (NAFTA) countries or even private sports organizations such as the International Association of Federation Football (FIFA) or the Court of Arbitration for Sport (CAS), have developed clearly differentiated legal processes beyond their role as mere policy consultants. Supranational law can influence, limit, and bind national sovereignty in many ways with respect to different issues such as taxation, international commerce, and environmental legislation. ${ }^{27}$ Moreover, in the last decades, several supranational legal institutions have developed features that were typical of the national legal systems-namely, the establishment of courts, procedural rules, and legislation. ${ }^{28}$ Nevertheless, these mechanisms are hardly subject to any form of sovereign statehood. And it was exactly this fact that led some authors to see them as a part of a world-statehood in the making. ${ }^{29}$

Two other forms of nonstate legal regulation are also worth mentioning. Both are primarily grounded in the so-called spontaneous field of private market economic and corporate practices. The highly sophisticated legal structures of lex mercatoria have gained great importance in the last decades. ${ }^{30}$ Partly, this philosophy has been reinforced by states that "relaxed their conditions for enforcing private

26. See Sol Picciotto, Networks in International Economic Integration: Fragmented States and the Dilemmas of Neo-Liberalism, 17 Nw. J. INT'L L. \& BUS. 1014, 1040-41 (1997).

27. See PICCIOTTO, supra note 22, at 50-53.

28. See Poul F. Kjaer, Law and Order Within and Beyond National Configurations, in The FinanCial CRisis in CONSTITUTIONAL PERSPeCtive: The Dark Side of Functional DifFERENTIATION, 395, 395-402 (Poul F. Kjaer et al. eds., 2011).

29. See Mathias Albert, Einleitung: Weltstaat und Weltstaatlichkeit: Neubestimmungen des Politischen in der Weltgesellschaft [INTRODUCTION: WORLD STATE AND WORLD StatehoOd: New DeRTEMinations OF THE POLITICAL IN THE WORLD SOCIETY], in WELTSTAAT UND WELTSTAATLICHKEIT: BEOBACHTUNGEN GLOBALER POLITISCHER

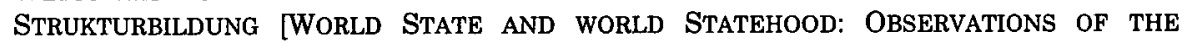
Formation of Global Political Structures ] 9 (Mathias Albert \& Rudolf Stichweh eds., 2007) (Ger.).

30. See, e.g., Nikitas E. Hatzimihail, The Many Lives-and Faces-of Lex Mercatoria: History as Genealogy in International Business Law, LAW \& CONTEMP. PROBS., Summer 2008, at 169; Peter Mazzacano, The Lex Mercatoria as Autonomous Law, 4 CoMP. RES. L. \& POL. ECON. 1 (2008). 
arbitration agreements, procedures and awards."31 Through various mechanisms of legal management, the contract law of corporations was in the position of building internal mechanisms of normative hierarchization, making possible problem solving exclusively based on contracts without reliance on state legislation. Moreover, private lawyers or courts increasingly externalize disputes about contractual agreements to arbitration proceedings. ${ }^{32}$ Another important type of nonstate transnational rule concerns the internal governance practices of corporations. $\square$ Administered centrally and from within inter-firm networks, transterritorialized globe spanning company activities bring together a multitude of autonomous organizational and economic actors that can easily exhaust the traditional regulatory aspirations of nation states and other political bodies." 33 The emergence of an "ever more expanding body of self-regulatory rules" makes it gradually more difficult to draw any lines "between official law and non-official law, between hard and soft law, ultimately between law and non-law."34 Transnational corporations very often develop "internal ordering and mechanisms which aim to ensure their ability to transplant meaning components, such as products, capital and human resources into a whole range of different configurational settings." 35

The expansion of the regulatory powers of inter-, supra-, and transnational organizations has been largely facilitated in the last three decades. On the one hand, the political decisions of the states regarding economic and commercial integration have led to the emergence of new forms of internationalized governance. ${ }^{36}$ On the other hand, the emergence of new instruments of global governance has developed a legal dimension of its own, setting free the expansive dynamic of functional social sectors that are not limited by political or territorial boundaries.

31. See PiCciotTo, supra note 22 , at 57.

32. See GunTHER TeUBNer, 'Global Bukowina': Legal Pluralism in the World Society, in GLOBAL LAW WithouT A STATE 3, 16-17 (Gunther Teubner ed., 1997).

33. Peer Zumbansen, Transnational Law, in ElgaR ENCYClopedia of CoMPaRATIVE LAW 738, 742 (Jan M. Smits ed., 2006) (U.K.).

34. Id. at 742-43.

35. Kjaer, supra note 28 , at 421.

36. See Robert O. KeOHANe, Governance in a Partially Globalized World, in Power AND GOVERNANCE IN A PARTIALlY GLOBALIZED WORLD 245 (Robert O. Keohane ed., 2002). 


\section{TRANSNATIONAL CONSTitutionalism: FUnCTIONAL SOCIAL ORDERING BEYOND THE STATE}

Problems regarding the structures of global governance are no longer a matter solely of interest to diplomats, international lawyers, or public regulators. In the twenty-first century, problems of everyday life increasingly appear to be connected to global and transnational issues. ${ }^{37}$ Transnational corporations violate human rights in different countries while producing computers or tennis shoes; ${ }^{38}$ the WTO makes decisions concerning the use of genetically modified organisms (GMO) that endanger the environment in remote localities in Latin America or in big cities in Europe. ${ }^{39}$ And the consciousness about these processes and causal connections becomes known through the mass media.

Admittedly, a broad array of global problems and decisions of global forums are experienced only locally and have a clearly political and even constitutional quality. These problems and decisions concern not only state policies, but also civil, political, and social rights, which are continuously challenged by private transnational actors and regulators. Various authors and commentators have described an increasing process of legalization taking place within global structures of governance on the transnational level. These processes have been described "as involving a fragmentation, hollowing-out, disaggregation, or decentring of the state," entailing a "devolution of specific functions to specialized regulators accompanied by new types of public-private interactions." 40 The very idea that there is a global legal system in the making breaks with the traditional framework of constitutional theory, namely the two core ideas of national law: the territoriality and the unity of the legal system.

37. See David Kennedy, The Mystery of Global Governance, in RULING THE WORLD?: CONSTITUTIONALISM, INTERNATIONAL LAW, AND GLOBAL GOVERNANCE 37, 37-40 (Jeffrey L. Dunoff \& Joel P. Trachtman eds., 2009).

38. See generally César A. Rodríguez-Garavito, Global Governance and Labor rights: Codes of Conduct and Anti-Sweatshop Struggles in Global Apparel Factories, 33 PoL. \& SoC'y 203 (2005) (describing working conditions in apparel factories in Mexico and Guatemala).

39. This issue is certainly extremely controversial. There is particular concern about the social, cultural and ecological impacts of GMO on the local level, especially in less developed countries. See, e.g., MARIE LUSSER ET AL., INTERNATIONAL WORKSHOP ON SOCIOECONOMIC IMPACTS OF GENETICALLY MODIFIED CROPS CO-ORGANISED BY JRC-IPTS AND FAO (2012), available at http://www.fao.org/docrep/015/ap016e/ap016e.pdf; Panel Report, European Communities-Measures Affecting the Approval and Marketing of Biotech Products, WT/291/R, WT/DS292/R, \& WT/DS293/R (Sept. 29, 2006).

40. See Sol Picciotto, Constitutionalizing Multilevel Governance?, 6 INT’L J. Const. L. $457,457-58$ (2008). 
Indeed, legal and political theories have always been especially concerned with territorial boundaries of legal and policy regimes; specifically, the problem of jurisdiction. This was the core of constitutional theory and the legal and political reflection of the "Keynesian-Westphalian paradigm."41 But it is exactly this "grid of clear borders" between regimes that has been challenged by the process of social and legal transnationalization. ${ }^{42}$ The most striking consequence is that, today, there is no "sovereigntist order of orders" or political metaprinciple of authority toward which we can orientate the analysis on the transnational level.43 Specifically, we can no longer take for granted that courts and political authorities relate to each other only on the basis of hierarchical (if internal to a domestic order) or horizontal mechanisms with clear territorial boundaries delimitating their jurisdictions. Rather, several forms of supra-, trans- and infranational laws "have created complex interactions between a variety of adjudicative and regulatory bodies at different levels" 44 involving both competition and coordination among them. As always, the relevant interpretative assumptions legal professionals have to deal with concern "the contextually appropriate choice of law rules," although transnational rules do not stand above the systems to which they apply. ${ }^{45}$ Instead, they are mostly formulated or interpreted "in the context of their own system" 46 in deference to and under the selfvalidating terms of their own orders. Thus, legally pluralistic explanations fit very well with the new global order of multiple transnational regimes and political layers in which we live.

Looking at the interactions of national, international, and transnational law is productive because it reveals how world society is structured not only around political organizations (like the state), but along functional structures operating globally across boundaries. ${ }^{47}$ The description of an increasing fragmentation that has dominated the debate over global governance regimes in past years, far from being only

41. Nancy Fraser, Reframing Justice in a Globalizing World, 36 NEW LEFT REV. 1, 1 (2005).

42. See, e.g., MORITZ RENNER, ZWINGENDES TRANSNATIONALES RECHT. ZUR STRUKTUR DER WIRTSCHAFTSVERFASSUNG JENSEITS DES STAATES [MANDATORY TRANSNATIONAL LAW. ON THE STRUCTURE OF THE ECONOMIC CONSTITUTION BEYOND THE STATE] 91-168 (2011) (Ger.) (for examples of the mandatory dimension of transnational legal orders).

43. See Neil Walker, Beyond Boundary Disputes and Basic Grids: Mapping the Global Disorder of Normative Orders, 6 INT'L J. CoNST. L. 373, 376 (2008).

44. Picciotto, supra note 40 , at 461 .

45. Walker, supra note 43 , at 377 .

46. Id.

47. Peer Zumbansen, Comparative, Global and Transnational Constitutionalism: The Emergence of a Transnational Legal-Pluralist Order, 1 GLOBAL Const. 16, 25 (2012). 
a fashionable reference to post-modernist tendencies, ${ }^{48}$ arose from the very structures of world society set free by its process of transnationalization. It corresponds to the increasing processes of differentiation, which states are not able to prevent, that are driven by the growing self-referent dynamics of economy, science, culture, health, transport, and sports in a global society. ${ }^{49}$ The legal limits of the global legal regimes are therefore formed "by invisible colleges, invisible markets and branches, invisible professional communities, invisible social networks that transcend territorial boundaries." 50 And the sources of legal norms in these regimes are the self-organized processes of highly specialized functional sectors. Indeed, prominent lawyers have observed this phenomenon from their privileged positions for observation of evolutionary trends in international law. ${ }^{51}$ As Martti Koskenniemi poses it:

Specializations such as 'trade law', 'human rights law', 'environmental law', 'criminal law', 'security law', 'European law' and so on started to reverse established legal hierarchies in favour of the structural bias in the relevant functional expertise. Even though this process was often organised through intergovernmental organisations, the governmental delegations were composed of technical (economic, environmental, legal) experts in a way that transposed the functional differentiation at the national level onto the international plane. ${ }^{52}$

If legal pluralism under the Keynesian-Westphalian framework of (state-centered) constitutional orders was just an external pressure for national legal systems, "[u]nder the new order, pluralism is internalwritten into the emergent frame[work] itself." 53 It becomes part of the

48. MARTTI KosKenNIEMI, Legal Fragmentation(s): An Essay on Fluidity and Form, in SOZIOLOGISCHE JURISPRUDENZ: FESTSCHRIFT FÜR GUNTHER TEUBNER ZUM 65. Geburtstag [Sociological JuRisprudence. Commemorative Publication in HonoR OF GUNTHER TEUBNER'S 65TH BIRTHDAY] 795, 795-97 (2009) (Ger.).

49. FISCHER-LESCANO \& TEUBNER, supra note 12 , at 19.

50. TEUBNER, supra note 32 , at 8 (internal quotation marks omitted).

51. Study Group of the Int'l Law Comm'n, 58th Sess., May 1-June 9, July 3-Aug. 11, 2006, ๆๆ 1-2, U.N. Doc. A/CN.4/L.682; GAOR, 60th Sess. (Apr. 13, 2006).

52. Martti Koskenniemi, The Fate of International Public Law: Between Technique and Politics, 70 MOD. L. REv. 1, 4 (2007) (citations omitted).

53. Neil Walker, Taking Constitutionalism Beyond the State, 56 POL. STUD. 519, 539 (2008). 
very understanding of legal constitutionalism, ${ }^{54}$ and, therefore, it makes transnational constitutionalism, from the outset, a sort of "constitutional pluralism." 55 Accordingly, in order to offer an adequate description of contemporary legal orders, pluralist constitutionalism (as a description of the operating conditions of the legal system) must take into account the disorder among the boundaries of hierarchical legal regimes. ${ }^{56}$

Regardless of how exotic the idea of pluralist constitutional orders may be for many lawyers or political scientists operating on a national level, it can be made plausible with a few theoretical steps. If we depart from some basic assumptions of classical legal theory, it becomes clear that some kind of constitutional discourse must exist as soon as a legal order acquires a level of autonomy. Indeed, a legal regime can only exist autonomously if it is based on some sort of second-order organization of its scope and operation. In other words, it must dispose not only of rules addressed to human behavior itself, but also of rules regulating the validity of such rules. ${ }^{57}$ It must be so, since the validity of a rule cannot be justified within a legal system on the basis of external grounds or arguments. And this condition-the very condition of legal differentiation-must remain as long as law operates as a normative order in its own right.

Theories about the sources of law (Rechtsquellen) aim to solve exactly this problem by referring to second order dispositions that define the legal criteria a decision maker, such as a judge, must rely on when deciding the validity of a legal rule. ${ }^{58}$ Legal sources of last resort may be interpreted as natural law grounded in God's revelation or in reasonthe people, or even the people's spirit (Volksgeist), as it has been the case in its romantic and idealistic versions. ${ }^{59}$ Nevertheless, this kind of last foundation to legal validity has gradually become implausible in the context of modern legal theory, which is arbitrary, metaphysical, or traditional. Instead, this kind of legal validity has been replaced by the

54. Alexander Somek, The Constituent Power in National and Transnational Context 32-34 (Univ. Iowa Legal Stud., Research Paper No. 12-35, 2012), available at http://ssrn.com/abstract $=2172054$.

55. See Walker, supra note 9 , at 317; See TRANSNATIONAL Governance, supra note 7 , at $5-7$.

56. Walker, supra note 9 , at 337-38.

57. See id. at 342. See also Niklas Luhmann, Verfassung als Evolutionäre Errungenschaft [CONSTITUTION AS A EVOLUTIONARY ACHIEVEMENT], 9 RECHTSHISTORISCHES J. [RJ] 176, 184 (1990) (Ger.).

58. Andreas Fischer-Lescano, Globalverfassung: Verfassung der Weltgesellschaft [Global Constitution: THE CONSTITUTION OF THE WORLD SOCIETY], 88 ARCHIV FÜR RECHTS- UND SOZIALPHILOSOPHIE 349, 354 (2002) (Ger.).

59. See Frederick BeISER, HegEL 239-43 (Brian Leiter ed., 2005). 
assumption that the foundation of a legal rule can only be another legal rule. ${ }^{60}$ Therefore, legal validity has become a question of observing the legal system itself, namely legal rules of second order that define whether a certain rule fulfils formal (e.g., competences of initiative, administrative, or legislative procedures) and material (e.g., compliance with normative dispositions on human rights) conditions of validity. Distribution of legislative competencies and adjudicative competencies (Kompetenz-Kompetenz) were to be understood in this context as the "constitution in the material sense." 61

Certainly, constitutions have long been thought of as the result of a political decision that can only be ascribed to a delimitated polity. ${ }^{6}$ Following Carl Schmitt, constitutions have been referred to as an expression of the political unity derived from the very concept of sovereignty. The latter, for its turn, should be conceptualized as the sovereign's power "to decide on the state of exception." 63 In this context, the state as the political entity par excellence, has been seen as the only bearer of a political self-identity able to be endowed with sovereignty. 64

Under the new transnational constellation there are nevertheless regulatory processes making use of legal mechanisms without a state quality. Therefore, some questions arise as soon as we observe this global (dis)order of legal regimes. How should political and legal theory conceive of the legitimacy and legal validity of regulatory processes such as those of the European Union and its "comitology system," which enjoys a broad range of powers that cannot be directly derived from clear delegation by national political decisions?65 How should we conceive of the regulatory powers of private authorities in realms such as the cyberspace of the Internet, where decisions regarding disputes over IP addresses are made by the Internet Corporation for Assigned Names and Numbers (ICANN) without oversight by national or

60. See Luhmann, supra note 57 , at 185.

61. See, e.g., KELSEN, supra note 6 , at 222 (emphasis added).

62. See Somek, supra note 54, at 1, 6-9; Walker, supra note 53, at 527-29.

63. CARL SCHMitT, POlitical TheOlogy: Four ChaPTERS ON THE CONCEPT OF SOVEREIGNTY 5-15 (George Schwab trans., 1985) (emphasis added) (defining sovereignty); see also ERNST-WOLFGANG BÖCKENFÖRDE, RECHT, STAAT, FREIHEIT: STUDIEN ZUR RECHTSPHILOSOPHIE, STAATSTHEORIE UND VERFASSUNGSGESCHICHTE [LAW, STATE, Freedom: STUdies on PHILOSOPHY of LAW, THEORY OF THE STATE AND CONSITUTIONAL HistoRY] 344-66 (1991) (Ger.).

64. See Christoph Möellers, StaAt als ARgument [The State as aN ARGument] 256-71 (2000); see also Hans Lindahl, Constituent Power and Reflexive Identity: Towards an Ontology of Collective Selfhood, in THE PARADOX OF CONSTITUTIONALISM: CONSTITUENT POWER AND CONSTITUTIONAL FORM 9, 9-17 (Martin Loughlin \& Neil Walker eds., 2008).

65. See Christian Joerges \& Jürgen Neyer, From Intergovernmental Bargaining to Deliberative Political Processes: The Constitutionalisation of Comitology, 3 EUR. L.J. 273, 282 (1997). 
international state-based jurisdictions? ${ }^{66}$ How can the legal decisionmaking of the WTO, whose court decisions often have a crucial impact on issues like human rights, income distribution, and environmental problems, be conceived even if its powers were to be limited to trade-related issues? ${ }^{67}$

If we consider constitutional law as a sort of reflexive law operating within law and if we take the transnational movements toward the legalization of regulatory processes seriously, we must agree with the fact that there are already different forms of constitutional law at work in today's global processes of regulation, which are not of the same quality as national constitutional law. Transnational constitutional law assumes a highly pluralistic form in each of the fragmented legal regimes that compose the functionally differentiated structures of global governance. These regimes function as atopical transnational polities, ${ }^{68}$ which in no way can be called political in the same way states can. Within these regimes, constitutional norms refer not to political processes such as parliamentary decisionmaking or political conflicts between parties and elections, but to the specialized knowledge of a specific functional social sector. ${ }^{69}$ The trade regime has, for instance, its own primary and secondary norms, as well as its own adjudicative structures. And although its decisions can have relevant consequences for issues like labor rights, social inequality, access to medical treatment, and knowledge, ${ }^{70}$ they are formulated and expressed mainly in the language of trade law, usually with its narrow and highly naturalized understanding of private property rights. ${ }^{71}$ Yet, functional constitutional law is not limited to supra-, trans-, or international

66. TRANSNATIONAL GovernANCE, supra note 7, at 5-6.

67. See William Magnuson, WTO Jurisprudence \& Its Critiques: The Appellate Body's Anti-Constitutional Resistance, 51 HARV. INT'L L.J. ONLINE 121 (2010) (presenting the arguments that the WTO's Appellate Body does not function in the most effective way due to resistance in constitutionalization); Joel P. Trachtman, The Constitutions of the WTO, 17 EUR. J. INT'L L. 623 (2006) (discussing the constitution of the WTO in relation to various dimensions of typical constitutions).

68. Helmut WillKe, ATOPIA: STUdien ZUR atopischen Gesellschaft [ATOPIA: STUDIES ON THE ATOPIC SOCIETY] 107-23 (2001) (Ger.).

69. See Andreas Fischer-Lescano \& Gunther Teubner, Regime-Collisions: The Vain Search for Legal Unity in the Fragmentation of Global Law, 25 MiCH. J. INT'L L. 999, 1014-17 (Michelle Everson trans., 2004).

70. See generally Ernst-Ulrich Petersmann, The WTO Constitution and Human Rights, 3 J. INT'L ECON. L. 19 (2000) (arguing in favor of constitutional reforms of the WTO to promote civil society and human rights). See also Pietro Maffettone, The WTO and the Limits of Distributive Justice, 35 PHIL. SOC. CRITICISM 243 (2009) (positing a critical perspective that joining the WTO is not a "completely free policy choice").

71. See Sol Picciotto, Paradoxes of Regulating Corporate Capitalism: Property Rights and Hyper-Regulation, 1 OÑATI SOCIO-LEGAL SERIES, no. 2, 2011, at 1, 15-16. 
organizations. ${ }^{72}$ It also arises from a variety of contractual arrangements and intertwining processes between organizations, including states, corporations, and nongovernmental organizations (NGOs), that constitute regimes. ${ }^{73}$ Recalling Stephen Krasner's classical definition of regime: "[r]egimes can be defined as sets of implicit or explicit principles, norms, rules, and decision-making procedures around which actors' expectations converge in a given area of international relations."74

The emerging transnational constitutional law has a brand new character: it consists of sets of rules and rules about rules that are closely connected with specific forms of knowledge and specific distributions of social power in different issue areas. Each regime seems to develop its own constitutional law, which, for its part, relies on a particularly technical vocabulary. Further, "each such vocabulary is likely to highlight some solutions, some actors, some interests" to the detriment of others. ${ }^{75}$

But what are the political implications of this shift? Which interests does a specific regime highlight? If a decision of the WTO impairs the chances and opportunities of a group of individuals of a particular ethnic or cultural minority, is it possible for them to make political claims to a parliament or to a constitutional court of last resort? If the decision of an arbiter from a third country on a corporate dispute between two corporations of two other countries jeopardizes the right to choose and the economic freedom of some population in a fourth country, to whom could this population appeal? Should the answers to such problems be found only in the language of trade or competition law? A "spontaneous constitutionalization" of transnational processes of legalization that is based on the increasing autonomy of functional social sectors does not imply a "depoliticization of society."76 These are increasingly pressing questions that today's legal and political theory must face.

72. See Türküler Isiksel, On Europe's Functional Constitutionalism: Towards a Constitutional Theory of Specialized International Regimes, 19 CONSTELLATIONS 102, 106 (2012) (defining "functional constitutionalism" as the creation and organization of public power through a constitution which translates normative expectations built into that constitution into "government").

73. See TEUBNER, supra note 7, at 59-72.

74. Stephen D. Krasner, Structural Causes and Regime Consequences: Regimes as Intervening Variables, 36 INT'L ORG. 185, 186 (1982).

75. Martti Koskenniemi, The Politics of International Law-20 Years Later, 20 EUR. J. INT'L L. 7, 11 (2009).

76. See TEUBNER, supra note 7 , at 117-19. 


\section{The Politics of LaW: The "Political" of TRANSNATIONAL CONSTITUTIONALISM}

If we think about sensitive issues of today's international politics, such as genetically modified organisms, and consider the social, environmental, and economic consequences arising from them, a difficult question immediately arises: "What vocabulary would serve best to grasp [this] novel phenomenon?"77 Should we use the vocabulary of economics or environmental regimes? Should we use the language of human rights or the language of trade? A lot depends on this choice, because once we know which vocabulary will be used, we already have an idea of how it will be dealt with. ${ }^{78}$ As soon as a social problem has been ascribed to a specific regime, it becomes a matter of knowledge and science rather than a matter of politics. To this extent, transnational constitutionalism is not based on constitutional arrangements underpinned exclusively by traditional political institutions, such as nation states and their associations.

In fact, issue regimes, usually dominated by highly specialized epistemic communities, ${ }^{79}$ increasingly dominate policymaking and law at the transnational level. This fact is also reflected in the management of legal decisionmaking in global governance regimes, which have become the focus for experts in specific regulatory areas. Global governance refers increasingly to the provision of optimal benefits for the respective stakeholders of a specific specialized social sector. ${ }^{80}$ Social problems are therefore described according to a new vocabulary, which is very different from the vocabulary used in the context of democratic political constitutionalism. Rather, the language of governance regimes is based on the cognitive language of indicators and disciplinary measurements, making possible more neutral and technocratic decisionmaking. The proliferation of indicators becomes an important tool not only for public policy and corporate governance, but also for legal decisionmaking. ${ }^{81}$ Moreover, smart governance legitimates itself more on the basis of information management than on political agreement. Global regulations can be silently enforced through

77. Koskenniemi, supra note 48 , at 796 .

78. See id. at 797.

79. Peter M. Haas, Introduction: Epistemic Communities and International Policy Coordination, 46 INT'L ORG. 1, 3-4 (1992).

80. See Martti Koskenniemi, Formalism, Fragmentation, Freedom: Kantian Themes in Today's International Law, 4 No. FouND. 7, 13-14 (2007).

81. See Koskenniemi, supra note 52, at 4; Sally Engle Merry, Measuring the World: Indicators, Human Rights, and Global Governance, 52 CURRENT ANTHROPOLOGY (SUPPLEMENT 3) 83, 83 (2011). 
standards and rankings, and legal decisions become almost impossible to challenge on the basis of political arguments. ${ }^{82}$

As a consequence of this shift, one could promptly ask: Where is politics? Would the fragmentation of legal regimes and the technocratic decisionmaking of global governance represent a depoliticization of society? ${ }^{83}$ Would it still make sense to talk of politicization in the same way as the structures of a contentious politics-"politics in which people make concerted claims bearing on each other's interests" usually addressed to states? ${ }^{84}$ Would we not observe a post-democratic transformation of world politics, suppressing the potential for transformations arising from "political conflicts over interests?" 85 In the place of a democratic vocabulary of constituent power, should we not observe the emergence of a new vocabulary, mostly of technocratic disciplines?

Some authors react to this point by taking a step back and engaging in old-concepts politicization. Specifically, with regard to the legal discipline, they point out that politicization is not an exclusive phenomenon of the political system. ${ }^{86}$ Legal politicization, as well as advances in legal methodology, could also come into play when one thinks of mechanisms of representation and politicization of interests.

Actually, legal theory has been historically aware of the possibilities for politicization within the law. Since the nineteenth century, legal realism and the Free-Law School have claimed that it is impossible to limit legal decision-making to an exclusively literal and neutral interpretation. ${ }^{87}$ In the first half of the twentieth century, Hans Kelsen was also conscious of the fact that an ineluctable moment of creativity, which always has some political content, must lie beyond the logical structure of law, the actual object of study of legal science. ${ }^{88} \mathrm{Also}$, the Critical Legal Studies (CLS) have been occupied in "deconstructing"

82. Helmut Willke, Smart Governance: Governing the Global KNowledge SoCIETY 7-51 (2007). See also Winton Higgins \& Kristina Tamm Hallström, Standardization, Globalization and Rationalities of Government, 14 ORG. 685, 686-87 (2007).

83. TEUBNER, supra note 7 , at 114.

84. ChaRles TILly, CONTENTION AND DEMOCRACY IN EUROPE: 1650-2000 6 (2004).

85. COLIN Crouch, Post-Democracy 70-76 (2004).

86. See, e.g., TEUBNER, supra note 7, at 114-124.

87. KaRL LaRENZ, METHODENLEHRE DER RECHTSWISSENSCHAFT [METHODOLOGICAL THEORY OF THE LEGAL SCIENCES] 59-69 (1991) (Ger.); MORTON J. HORWITZ, THE TRANSFORMATION OF AMERICAN LAW, 1870-1960, 169-192 (1992).

88. KELSEN, supra note 6 , at 353 ("The task to get from the statute the only correct judicial decision or the only correct administrative act is basically the same as the task to create the only correct statutes within the framework of the constitution. Just as one cannot obtain by interpretation the only correct statutes from the constitution, so one cannot obtain by interpretation the only correct judicial decisions from the statute."). 
legal formalism by showing that law always bears some form of indeterminacy, which emerges in the very moment of legal decisionmaking. ${ }^{89} \mathrm{CLS}$, by the way, made a long career in the legal discipline, including international law. ${ }^{90}$ Drawing on this long tradition, a broad array of scholars and legal practitioners have tried to develop conceptual tools for understanding the role of politics within transnational and global law.

In fact, on a national level, the high complexity of contemporary societies has already demonstrated that legal questions cannot be understood as a mere result of methodologically oriented, neutral legal interpretation. As different authors have observed, the expansion of the scope of state activities and responsibilities has resulted in the emergence of "open-ended standards and general clauses in legislation, administration and adjudication," which induced a "turn from formalistic to purposive or policy-oriented styles of legal reasoning and from concerns with formal justice to an interest in procedural and substantive justice." ${ }^{11}$ As demonstrated by a long discussion over the paradoxes of the regulatory state, the increased complexity of regulation tended to always imply more regulation as a way to deal with the increased complexity of social relations that emerged from the first regulatory attempts. In the end, those who manage the regulatory mechanisms and their judicial control should have discretion. And as it has been argued in the context of the CLS, some internal politicization would necessarily emerge as the consequence of indeterminacy. ${ }^{92}$

It is exactly this tendency that seems to be more pronounced on the transnational level, although under very different structural conditions, since transnational law operates in the absence of many of the political structures of national political systems. Therefore, the politics of transnational constitutionalism does not assume the form of a political struggle between political parties whose interests are directly, or even advocatorily, involved in bargain or negotiation processes. Rather, the politics of transnational law takes into account that "[i]t is impossible to make substantive decisions within the law which would imply no

89. See, e.g., Duncan Kennedy, The Paradox of American Critical Legalism, 3 EUR. L.J. 359 (1997).

90. E.g., Martti Koskenniemi, The Politics of International Law, 4 EUR. J. I'NTL L. 4 (1990).

91. Roberto MANGaBeIRA UNGER, LAW IN MODERN SOCIETY: TOWARD A CRITICISM OF SOCIAL THEORY 194 (1976). See also Gunther Teubner \& Bremen Firenze, Juridification: Concepts, Aspects, Limits, Solutions, in JURIDIFICATION OF SoCIAL SPHERES: A COMPaRative ANalysis in the AREAS of Labor, CoRPORATE, ANTITRUST AND Social WELFARE LAW 3 (Gunther Teubner ed., 1987) (Ger.).

92. UNGER, supra note 91 , at 192-200. 
political choice."93 As long as any legal decision can be politicized, the increasingly technocratic legalization of transnational law, be it within lex mercatoria, within the lex digitalis of ICANN adjudication, or within WTO, might also be seen as the object of processes of politicization.

Different authors have pled to a productive use of this discovery as a source of hegemonic struggles over the legal frameworks' of transnational and global decisionmaking. Instead of accepting the rule of experts, whose power derives from their capacity to describe any problem in the language of a specific technical regime, the task is described as a hegemonic technique of exposing invisible forms of domination. The scope of legal critique has changed: "If [twenty] years ago it seemed intellectually necessary and political useful to demonstrate the indeterminacy ... . [of the legal language] today's critique will have to focus on the clash of different idioms ... . and highlight the way their competing descriptions work to push forward some actors or interests which leaving others in the shadows."94

Martti Koskenniemi, for instance, who is known for applying the CLS techniques to public international law, has tried in the last decade to describe the politics of transnational law with another language. For him, on this level, at stake is another kind of political struggle: "politics of re-definition." 95 Accordingly, it would not be so important to occupy the place of decision, but to decide over which language is to be used to describe a specific problem and how that language articulates its description..$^{96}$ The vocabularies of respective issue areas, appealing to neutral methods and scientific descriptions, would make it easier for a specific group to universalize a particular description of reality as reality itself. But reality can be described in very different ways depending on which vocabulary is used. The same problem, or legal dispute, can be described from the perspective of environmental sciences or from economics. And as a result, one can arrive at very different solutions. "To this extent the vocabularies act as 'ideologies' in the technical sense of reifying, making seem necessary or neutral something that is partial and contested"97

This increasingly ideological specialization of the vocabulary of global governance would be grounded in a new perspective of the law, which Koskenniemi calls a "managerial mind-set." This mind-set would be the consequence of "'deformalization,' 'fragmentation' and 'empire" in

93. Koskenniemi, supra note 90 , at 31 .

94. Koskenniemi, supra note 75 , at 11 .

95. Id. at 11.

96. Id. at $11-12$.

97. Id at 12 . 
the realms of international and transnational law. ${ }^{98}$ By deformalization, he understands "the process whereby the law retreats solely to the provision of procedures or broadly formulated directives to experts"; by fragmentation, "the splitting of law into functionally defined 'regimes"; and by empire, he understands "the emergence of patterns of constraint deliberately intended to advance the objectives of a single dominant actor, either through the law of irrespective of it." 99 The managerial mind-set would gradually replace the legal language law used to have in its politically constitutionalized form with functional dialects of transnational regimes. As a consequence of this fact, in the language of transnational law, government would become governance, responsibility would become compliance, and disputes would gradually become management problems. The managerial mind-set would become an interesting "unreflective version of legal literalism," since it does not do much more than interpret literal reality from the standpoint of its technical description by specialized disciplines. 100 The rule of experts is necessarily biased, since it is structurally supported by the specialized functional regime through which the world is disclosed. This form of ruling is then described as being very similar to those of the European Ancién Regimes. "Ancién régimes, after all, were also regimes, and the rule of law was imagined by Kant and other liberals against all that."101

Koskenniemi opposes the managerial mind-set from an antagonist perspective, which is grounded in the tradition of political constitutionalism. The "constitutional mind-set" corresponds to the political tradition drawing back to the Kantian motive for the existence of an internal legality of the law, where validity relies on its own internal normativity. Accordingly, law should be seen as a normative order in its own right, based on reason and on its self-legislative capacity. ${ }^{102}$ Following Kant's criticism of utilitarian reasoning and his argument that freedom must be understood as self-determination, Koskenniemi claims that "law is needed for legislation to exist, and legislation is needed for self-determination to be possible." 103 Thus, law must be the expression of a community's self-determining will.

Against the managerial mind-set, the Kantian constitutional mindset considers everyone's political interests. Notwithstanding, if, for Kant, the political dimension of law is ultimately limited by the moral

98. Koskenniemi, supra note 10 , at 13 .

99. $I d$.

100. Id. at 14 .

101. Id. at 17.

102. See IMMANuel Kant, GroundWORK For the METAPHysics of MORALS 49 (Allen W.

Wood ed., Allen W. Wood trans., 2002).

103. Koskenniemi, supra note 10, at 25. 
dimension of universalist reason, for Koskenniemi, (Kantian) moral politics are nothing but a political option that every legal practitioner has to make. Kantian moral politics becomes, thus, a political project, which has to be affirmed in the face of other political projects. In the special case of international law, it must be established against the managerial mind-set of the deformalized law of empire. Constitutionalism is, therefore, understood as a political mind-set. The task of today's politics of law is to pursue the affirmation of constitutionalism as a collective project, which challenges the expert rule. By this operation, however, the political project of Kantian universalism becomes disconnected from the Kantian premise of universal reason, effective in the institutional mechanisms of private and public self-legislation. It becomes a political project among others, struggling for hegemony over the "constitutional vocabulary" of global and transnational law without depending on its structural conditions. ${ }^{104}$

For those defending a politicization of law, without regard to its political democratization through institutional and political reforms, the central question of today's politics of law becomes the following: "what kind of ... law, and what type of (and whose) preference" determine how social problems become legally framed?105 Nevertheless, the redefinition of the managerial world in the constitutional language of a "Kantian mind-set" or of public administrative law does not rely on the "intrinsic worth of those vocabularies"; rather, it makes sense only for the sake of "the critical challenge they pose to today's culture of apolitical expert rule."106 In other words, for Koskenniemi and for other scholars following this kind of deconstructionist-Gramscian approach, the Kantian mind-set of constitutionalism works as the basis for a counter-hegemonic technique, which strives for control of the ruling language within international law.

The struggle for the hegemony over the constitutional language of international and global law could be defined, in a radical Gramscian sense, as the struggle for defining as universal "a particular way of living and thinking, a Weltanschauung." 107 Accordingly, struggles over the hegemony of legal language normalize particular worldviews through the formal language of law, offering them a link to universalization and compatibility. Through this operation, a particular legal hegemony will have the prerogative of "creat[ing] and maintain[ing] a particular mode of coexistence and of individual relations, ... mak[ing] certain usages and modes of behaviour disappear

104. See id. at 35 .

105. Koskenniemi, supra note 75 , at 17.

106. Id.

107. Buckel \& Fischer-Lescano, supra note 11, at 442. 
and ... disseminat[ing] others" by making certain usages and modes of behavior disappear and disseminating others. ${ }^{108}$ The constitutional discourse articulating the language of law from within the legal system itself would be at the very core of today's possibilities of politicizing world society.

In a global system of governance that is mostly reproduced by fragmented forms of transnational law, the language that articulates meaning and controls the validity of legal norms at this level is a defining medium. Within the language of transnational constitutionalism, the particular worldviews of certain social groups and functional sectors can be universalized and transformed into the ruling form of life across the entire world society. These struggles thus become the privileged point where anti-hegemonic techniques should take place and politics of law should be carried out in an "emancipatory" way.

\section{CONCLUSION}

The attempts to describe alternative mechanisms of politicization in transnational law are valid, but in many ways they are also limited. Relying on the radical assumption that society can always be described as a political object, the authors pursuing this thread of argumentation seemingly fail to explain the circumstances under which political struggles (also in the form of struggles over hegemony) might play an important role in social evolution.

Certainly, political projects can influence the course of historical developments as soon as they determine how decision making within the law, but also in other social domains (such as art, science, and sports), is carried out. However, it is hard to accept the claim that the language of politics, and consequently the language of hegemonic struggles, has always been available for social actors (and also for political and legal theoreticians) in human history. In other words, the very idea that anti-hegemonic techniques can be employed to change dominant worldviews is not a given without further social conditions making it possible. Also, such conditions surely need further sociological specification if we want to understand how to politicize world law under today's conditions of fragmentation and functional constitutionalization. Hence, to understand how collective decision-making, and the (collective) political projects it always implies, ${ }^{109}$ can be the object of social struggles, political and legal theory must understand which

108. Id. at 447 .

109. See Armin Nassehi, Der Begriff des Politischen und die Doppelte Normativität der "Soziologischen" Moderne [THE CONCEPT OF THE POLITICAL AND THE DOUBLE NORMATIVITY of THE "Sociological” Modernity], 14 Soziale WeLt 133 (2003) (Ger.). 
conditions must be present, making visible the possibility of striving for the hegemony of forms of life and worldviews. That is to say that it has to consist of an institutional political project.

In what follows, I would like to raise some questions about the institutional and sociological conditions of the politicization of law. Elsewhere, I have tried to reflect on this issue from the perspective of sociological systems theory. ${ }^{110}$ This time, I intend to draw on the insightful thoughts of the political philosopher Claude Lefort. In order to follow the same thread, my argument consists of the claim that the politicization of law within the legal system is a very improbable phenomenon that must rely on complex social structures and institutions. My intuition is that, unless some of these structures-or their functional equivalent-are present on a transnational level, the politics of international law will remain limited to totalitarian forms like those Martti Koskenniemi has described as imperial.

If Koskenniemi argues that the new global governance regimes seem like new totalitarian "ancien régimes" based on naturalistic comprehensions of the law, he should also keep in mind that, under the ancien régime, citizens were not able to criticize the sovereign. ${ }^{111}$ And this was so not only because the "regime" was a totalitarian one, which left no room for free expression and critique by its citizens, but also because society disposed of no vocabulary to describe political and legal decisionmaking as possible objects of politicization. In fact, under traditional forms of society, not only is the political system prevented from developing internal forms of social conflict, but also other social spheres are usually integrated under a totalitarian ethical life, which assigns very narrow predetermined social roles and positions for every social group and individual in society. ${ }^{112}$ Under the social organization of ancien régimes, individuals and groups of individuals were not able to develop a self-understanding that enabled them to see themselves as political actors. ${ }^{113}$ The law was also subjected to totalitarian forms of organization, which made the law little more than a medium for the reproduction of the structural hierarchies of society. ${ }^{114}$ Under these

110. See HoLMES, supra note 15 , at $61-75$.

111. See CHRIS THORNHIL, A SOCIOLOGY of Constitutions: Constitutions AND State LegitimaCY IN HistoriCal-Sociological PERSPECTIVe 88-112 (2011).

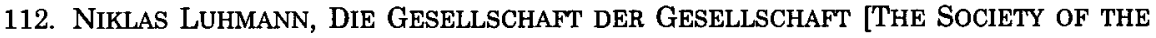
SOCIETY] 678-707 (1997) (Ger.).

113. See id. at 1016-1036. See also NIKLAS LuHMANN, Individuum, Individualität, Individualismus [Individual, Individuality, Individualism], in GESELLSCHAFTSSTRUKTUR UND SEMANTIK. STUDIEN ZUR WISSENSSOZIOLOGIE DER MODERNEN GESELLSCHAFT BAND 3 [Social Structure and Semantics: Studies on the Sociology OF KNowledge of MODERN SÚCIETY VOLUME 3] 149, 208-215 (1993) (Ger.).

114. See HolmES, supra note 15, at 81-88. 
circumstances, legal decisionmaking was not the task of a differentiated legal system subject only to its own logic. Hence, it was simply impossible to conceive of a politics of law that could be carried out in the form of struggles over the hegemony of a "constitutional language." Ancien régimes are normative orders that integrate every other social order under the same natural or metaphysical semantics, which must give meaning to social life. To some extent, it is not a hegemonic form of domination; it is a total form of domination that leaves no place to political contestation. The possibility of politicizing the law from within depends, therefore, on some social condition. It depends on the social differentiation of the legal systems of other social orders and on what Claude Lefort called the moment of the political. ${ }^{115}$

For Claude Lefort, the moment of the political depends on a deepseated social transformation of society. ${ }^{116}$ Traditional societies were, until modernity, conceived as a social body in which politics, religion, ethics, and science were unified. The process that set free the social possibilities of observing and identifying social, political, and legal contingencies-thus making possible the politicization of society and also of law-had its roots exactly in the fragmentation of that unity. This process of fragmentation began under the political order of the ancient regime, ${ }^{117}$ but it would have been stabilized only after an institutional transformation that would have made possible a proceduralization of political conflicts through the inclusion of individuals in political processes.

For Lefort, the social unity jeopardizing the social visibility of contingency under the rule of the ancien régime could be depicted as Kantorowics' metaphor of "the two bodies of the King."118 "The image of the king's body as a double body, both mortal and immortal, individual and collective, was initially underlined by the body of Christ." 119 In fact, by the seventeenth century, this political unity had been substantially weakened. "[N]ew models of sociability emerged as a result of the growth of individualism" and following "the development of the state administration, which tended to make the latter appear as an

115. Claude Lefort, The Image of the Body and Totalitarianism, in THE POLITICAL Forms OF MODERN SOCIETY: BUREAUCRACY, DEMOCRACY, TOTALITARIANISM 292, 305 (Claude Lefort \& John B. Thompson eds., 1986).

116. Id. at 302.

117. See Claude Lefort, The Question of Democracy, in DEMOCRACY AND POLITICAL Theory 9 (David Macey trans., 1988). See also Oliver MarcharT, PoST-Foundational Political Thought: Political Difference in NANCY, Lefort, Badiou and LaClau 9091 (2007).

118. ERnst H. Kantorowics, The King's Two Bodies: A Study in MEdieval Political THEOLOGY 441-48 (1997).

119. Lefort, supra note 115 , at 302. 
independent, impersonal entity." 120 What Alexis Tocqueville called a "democratic revolution"-and which represented an increasing separation of the distinct logics of different social sectors such as law, science, and politics-could not guarantee the formation of a democratic political order. ${ }^{121}$ The consequence of that fact was that the possibilities of politicization and contingency observation remained limited: "the changes that occurred did not entirely eliminate the notion of the kingdom as a unity, which was both organic and mystical, of which the monarch was at the same time the body and the head." 122

Hence, "the kingdom of unity" was not abolished immediately as a consequence of modernization and individualization. Even the emerging bourgeoisie, who had tried to eliminate the body of the king symbolically and in reality through the decapitation of Louis XVI, had tried to reestablish some sort of social unity. ${ }^{123}$ Timeless and ahistorical ideals like unlimited private property, the state sovereignty, culture, and nation have served exactly this purpose, as they have aimed to find new political orders based on social foundations that could not be the object of political contestation. ${ }^{124}$

For Lefort, it is clear that the differentiation of politics, law, and science can only be stabilized through an encompassing process of political democratization, which depends on the legal institutionalization of the democratic revolution through the constitutionalization of political rights. ${ }^{125}$ This would be the only way through which modern society could keep the social locus of power empty, hence avoiding any idea or social claim for power that could replace the social place, which has been occupied by that lost unity represented by the king's body. That is to say, avoiding the reemergence of "renewed" expressions of the ancient régime. ${ }^{126}$ For Lefort, it is this reciprocal relation between the emergence of a democratized political system and the differentiation of an autonomous legal, which makes the exercise of power to become subject to "procedures of periodical redistributions," in the form of electoral contests. ${ }^{127}$ As a consequence, "the locus of power becomes an empty place," and democratic politics can emerge as "an institutionalization of conflict." 128

120. Id. at 302 .

121. Id. at 303 .

122. Id. at 302 .

123. Id. at 304 .

124. See Id. at 302-03.

125. MARCHART, supra note 117 , at 91.

126. See Claude Lefort, Politics and Human Rights, in THE Political Forms OF MODERN SOCIETY: BUREAUCRACY, DEMOCRACY, TOTALITARIANISM, supra note 115, at 239.

127. Lefort, supra note 117, at 19.

128. Id. 
The legal system, on the other hand, can observe the emergence of internal forms of contingency, which also allows for internal politicization movements.

The process of political democratization depends, however, not only on the constitutionalization of rights. In his studies about the totalitarian phenomenon, Lefort goes further in his defense of the process of democratization as the key for understanding the possibilities of social differentiation and social politicization of different spheres of society. By looking at how the visibility of social contingency would be restricted under totalitarian regimes, he attempts to show how the very possibility of the emergence of social conflicts must be institutionalized if social contingency is to remain visible. ${ }^{129} \mathrm{He}$ argues that constitutional processes are necessary to legalize and institutionalize conflicts as a permanent possibility and for the social contingency to remain active. ${ }^{130}$ Accordingly, societies living under totalitarian political regimes, which do not dispose of legally regulated democratic processes of conflicts, tend to observe an increasing de-differentiation process between the social spheres of political power, law, and (even scientific) truth, as they become reunified under the same totalitarian normative order. And, thus, the social visibility of contingency in these different spheres becomes more and more jeopardized.

If the legal system cannot rely on a stable "institutionalization of conflicts," it becomes increasingly vulnerable to timeless conceptions of unity, which can limit internal forms of politicization even if there are sophisticated techniques of legal management and reasoning in place. The totalitarian experiences from the twentieth century are rich with examples of political forms of ruling that could barely be said to be based on lawless regimes. In spite of that, it is clear that under these regimes, the legal system has been exploited in the interest of political rulers and has become predominately closed for internal forms of politicization. According to Lefort, the law, under these contexts, has very often been the object of social processes of materialization. ${ }^{131}$ As an example of this phenomenon, he mentions the "law of life" of Nazionalsozialismus and the "law of history" of the Soviet Union. ${ }^{132}$

For Lefort, it appears that the democratic societal form of organization is not limited to the political system. Rather, it implies an institutionalization of conflict among society, with many consequences

129. Claude Lefort, Hannah Arendt and the Political, in DemocraCY AND PolitiCAL THEORY, supra note 117 , at 51 .

130. Lefort, supra note 117 , at $18,19$.

131. See generally CLAUDE LEFORT, COMPLICATIONS: COMMUNISM AND THE DILEMMAS OF DEMOCRACY (2007).

132. Lefort, supra note 129 , at $45,48$. 
in different social contexts. ${ }^{133}$ The constitutionalization of human rights and the institutionalization of conflict through electoral competition and free universal suffrage enables not only the fragmentation of a unified normative order of the ancient régime, but also allows for a social contingency in different sectors of society. ${ }^{134}$ In political democracy, social forms of hierarchy and arbitrary traditions become continuously exposed to the possibility of critique not only within political organizations, but also along different social functions and social sectors.

As expressed by Lefort, the political constitutionalization becomes, therefore, the essential condition that enables the social locus of power to be kept empty. Only the democratization of the political system through its constitutional form can set free the social visibility of contingency, making possible the politicization of decisionmaking within different social sectors, including the law. Therefore, Lefort seems to understand the democratization of politics as a basic condition of the most characteristic trait of modern society:

Once power ceases to manifest the principle which generates and organizes a social body, once it ceases to condense within its virtues deriving from transcendent reason and justice, law and knowledge assert themselves as separate from and irreducible to power. And just as the figure of power proves to be bound with the temporality of its reproduction and to be subordinated to the conflict of collective wills, so the autonomy of law is bound up with the impossibility of establishing its essence. As power, law and knowledge becomes disentangled, a new relation to the real is established; to be more accurate, this relation guaranteed within the limits of networks of socialization and of specific domains of activity. Economic, technical scientific, pedagogic and medical facts, for example, tend to be asserted and to be defined under the aegis of knowledge and in accordance with norms that are specific to them. ${ }^{135}$

Democratic politics becomes the central condition for the very possibility of any politicization of law, as it makes possible the visibility

133. See MARCHART, supra note 117 , at 91 .

134. See Lefort, supra note 117, at 19.

135. See id. at 18. 
of contingency within the system. For Lefort, there is a double inscription of the political in society as soon as a democratic constitutionalization of politics takes place. The political system "represents within society its own forgotten foundation, its genesis in a violent, abyssal act ... politics as sub-system represents the Political (subject) for all other social sub-systems." 136 Once the differentiation of politics has been made possible, it is possible for other systems to organize internal forms of politicization in their own language.

If we think of the assumptions being brought about by the constitutional reflections on transnational law, we will notice that those assumptions clearly tend to treat legal politicization to some extent as an ahistorical, asocial, and unconditioned phenomenon that accompanies any legal regime. To this extent, Lefort's lessons can be very useful in explaining transnational constitutionalism. If the nationstate, and thus the constitutional form of politics, loses its force as the sole source of legal production and, as a consequence, the political, constitutional form of law cannot be deemed to be subject to the same structural conditions it used to be under democratic constitutionalism, it might also be the case that the internal visibility of the contingency of legal decisionmaking may become gradually lost or jeopardized. To this extent, it makes thorough sense, if Martti Koskenniemi speaks of the emergence of a "new" ancient regime of fragmented functional legal regimes, dominated by the rule of experts. In fact, it is not outside the description of a new sort of absolutism, namely in the form of deterritorialized regimes, based on the fragmented rule of disciplinary truth and carried out by technical institutions.

The political struggles being carried out in transnational law should be, however, the object of more theorization. To simply rely on the assumption that the most important task of critical legal thought, today, would consist of employing counter-hegemonic techniques against the growing rule of experts can be in many ways misleading. It is hard to believe that the political struggles in transnational governance can be conceived only as "politics of redefinition." The struggles over the hegemony of the language of transnational law cannot take for granted that the fragmented regimes of transnational governance can be politicized through the language of collective conflicts.

To this extent, Gunther Teubner seems to be right when he discards the possibility of political struggles recovering the language of politics in the functionally differentiated system of global governance. For him, it

136. Slavoj ŽIžEK, For THEY KNow Not What THEY Do: EnJoyment AS A POLITICAL FACTOR 194 (1991). See also URS STÄHELI, SinNZUSAMMENBRÜCHE: EINE DEKONSTRUKTIVE LEKTŰRE VON NIKLAS LUHMANNS SYSTEMTHEORIE [BREAKDOWNS OF MEANING: A DECONSTRUTIVIST READING OF NIKLAS LUHMAN'S SYSTEMS THEORY] 261 (2000) (Ger.). 
seems that any hope must rely solely on the conditions of these fragmented legal systems for producing an internal responsivity toward their environments in the language of their own specialized functions. ${ }^{137}$ It means that there would be no place for a politicization of legal decisionmaking based on the language of interests or the language of a counter-hegemonic political project. Rather, it would be, for instance, a problem of economics if the economic legal regimes are not able to deal with the problems of increasing inequality and social exclusion. Only in the language of economics, and according to its own language, could such problems be faced. For Teubner, however, it is also not really clear, if the functionally differentiated global legal system can develop the necessary features to offer such internal responsivity.

If one looks at today's forms of governance at the global and transnational levels, it is hard not to become pessimistic about the real possibility of changing and politicizing their fragmented legal regimes. On the other hand, if we reconstruct the social conditions of political constitutionalization, as we did above drawing on Lefort's work, it must be the case that the absence of a global state will necessarily imply the de-differentiation of the law in some form of a deformalized and fragmented order of management, which becomes an easy prey for private interests that can speak the language of governance. Maybe, the social struggles for the hegemony of the transnational legal language should be described neither as a war between disciplines-where public international law would play the role of the Universal as a "Kantian" constitutional mind-set against the Particular of the various managerial mind-sets-nor as a struggle over the constitutional language of transnational law. Rather, it could be the case that the best description of a new politics of transnational law is one that reflects the necessity of its democratization. As Andreas Fischer-Lescano and Sonja Buckel paradoxically show, the political struggles in world law must link the legal language with the legally creative social movements that are the only force that can force transnational law to accept new forms of political inclusion. ${ }^{138}$ This should not be conceived, however, as a struggle for the universalization of some "aesthetical judgement" that could universalize particular forms of suffering as if they were to be felt collectively. Even though it sounds philosophically possible, the aesthetical language needed can only emerge and be effective under highly selective conditions: the very idea of a free and universal comprehension of aesthetical beauty also has its roots in modern differentiation of free artistic expression, which must also be based on

137. See TEUBNER, supra note 7 , at 117-23.

138. See Buckel \& Fischer-Lescano, supra note 11, at 450-52. 
constitutional and inclusive rights. Instead of insisting on such heterodox and abstract assumptions of an ahistorical politicization of society, legal theory should go back to the institutional level where political inclusion, participatory politics, and the legal institutionalization of social conflicts can find its material basis. This is the lesson that can be drawn from Lefort and from other theoretical approaches.

The politics of transnational law would only make sense if it was focused on the institutional level of democratic constitutionalization. Since it is very improbable that we can come back to the institutional form of democracy we witnessed in the nation state, it is clear that one of the most important practical and theoretical questions of our day consists of whether is it possible for the transnationalized world society to develop functional equivalents of the political constitution on the transnational level.139 A transnational democracy would surely be different from a national one. It must, however, be able to include vast sectors of society in procedural forms of decisionmaking that could be subject to extremely politicized forms of social conflict and critique.

139. Hauke Brunkhorst, Solidarity: From Civic Friendship to a Global Legal COMMUNITY 151-61 (Jeffrey Flynn trans., 2005). 
